\section{Obituary: Melvin H. Mueller}

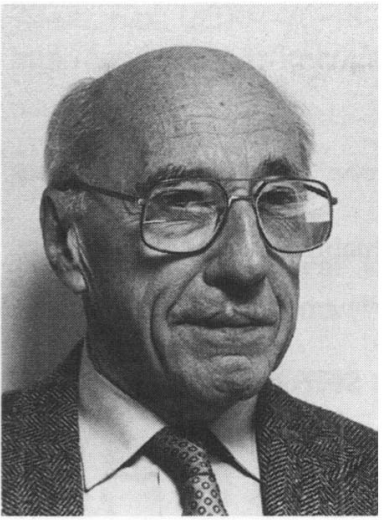

Our friend and colleague, Mel Mueller passed away on Friday, 28 June 1996 in Illinois. Mel was born in 1918 in Iowa and spent most of his working life at the Argonne National Laboratory where, at retirement, he was a Senior Scientist. He received a Ph.D. in Chemistry from the University of Illinois in 1949. Mel was one of the leading lights in actinide structural research and authored many papers about their structures. Until recently, he was still reporting on research carried out with his Argonne National Laboratory colleagues. The technical contributions made by him in the diffraction field were quite significant. His least-squares refinement program that was written with LeRoy Heaton is considered one of the best and, even today, is powerful in both its flexibility and simplicity.

While Mel had a long-time association with the International Centre for Diffraction Data (formerly the Joint Committee on Powder Diffraction
Standard), upon his retirement from Argonne he became very active and served in a variety of committee roles. Of these, probably the most fruitful was his long association with the Metals \& Alloys Subcommittee. This committee worked diligently for many years to ensure that the recently produced Metals \& Alloys Search manual was current, up-to-date, and published in a form most useful to both experienced users and newcomers to the field. Mel chaired the Grants-in-Aid Subcommittee for a number of years. During this period the number of grant recipients, particularly overseas grant recipients, increased significantly, much of this increase being catalyzed by Mel's enthusiasm and diligence. Among his many commitments, Mel served on the ICDD Board of Directors from 1992 to 1996 . He also contributed patterns to the Powder Diffraction file, both as a grant recipient and as a contributor

Mel was fond of working in his garden, and his personal interests included art and music; he enjoyed attending concerts of the Chicago Symphony. He had been on the school Board in Elmhurst, at one time serving as President.

Mel Mueller is remembered by his colleagues at the ICDD as a competent scientist, an enthusiastic co-worker, and a compassionate human being. He will be truly missed. 